\title{
REAL ESTATE CADASTRAL DATA COLLECTION PROBLEMS, IMAGING AND WORKS INTENSITY IN LITHUANIA
}

\author{
Rimvydas Gaudèšius \\ National Land Service under the Ministry of Agriculture, Gedimino pr. 19, Vilnius \\ E-mail: rimvydas.gaudesius@nzt.lt
}

Received 28 November 2013; accepted 24 February 2014

\begin{abstract}
Immovable properties mainly include land and objects related to it and that are not possible to be moved from one place to another without changing their purpose and decreasing their value. Legal ownership to this property has always been and will always be important for an individual. Registration of the real estate (thereinafter - RE) and information about drawn up ownership is the foundation for creation of any other systems. Geographic information system (thereinafter - GIS) being used wider in all over the world, data bases containing information about registered property are being created. RE registration systems are related to economically and politically advanced societies and whereas states are differently advanced on a social environmental level, this process is also unevenly developed in different countries; the importance, accuracy and presentation of registered data to concerned society are valued differently, too.
\end{abstract}

The scientific article analyses real estate cadastral data bases existent in Lithuania that are created by different institutions, prevalent features of data evaluation and related problems. Characteristics of cadastral data collection in other states are also reviewed. Posed the problem of inaccuracy of cadastral data collected, who influences a dispute and frauds. Moreover, the article draws attention to the necessity to improve the process of works performed in Lithuania in order to simplify data determination and increase its accuracy. The article also shows the intensity of the work performed in the administrative areas and after calculations are made, further course of works will be forecasted.

Keywords: real estate, cadastral measurements, land plot, land owners, geographic information system.

Reference to this paper should be made as follows: Gauděšius, R. 2014. Real estate cadastral data collection problems, imaging and works intensity in Lithuania, Geodesy and Cartography 40(1): 14-26.

\section{Introduction}

Modern RE administration system - is methodologically arranged state system which collects, processes and registers data about RE and includes all kinds of RE data defined by legal acts, ownership and management rights to the RE, limitations and restrictions of the rights, also graphical information determined by measurements of their borders or outline. RE administration system consists of three main parts: cadastre, register and evaluation. RE cadastral data preparation and management defines RE objects - land plots, buildings, premises and engineering equipment. This stage examines the location of the RE objects and their qualitative characteristics. RE objects and material rights registration stage ensures legal status of RE objects and rights to them and provides information on who manages those objects and in what way. $\mathrm{Du}-$ ring RE evaluation process, qualitative and valuation data collection of RE objects is performed, as well as their evaluation and expression in RE cadastral and registry information data base (Gasilionis, Kasperavičius 2006). This RE administration system functions by following the regulations and other legal acts. The main laws are considered to be Law on Land, Law on Real Estate Cadastre, Law on Real Estate Register and Law on Geodesy and Cartography.

State enterprise Center of Registers (thereinafter SE Center of Registers) is responsible for maintaining Real Estate cadastre and register executive works. It registers material rights to the immovable property: ownership right, property trust right, management as an individual property right, easement, usufruct, 
surface right, long-term rent. Notes in the respective real property registry record may be made on the following legal facts: purchase-sale agreement, exchange agreement, donation agreement, tenancy agreement, commodate contract, mortgage, life annuity contract, common joint ownership, property rights restrictions to immovable property provided in contracts, other juridical facts as it is provided by law (LR nekilnojamojo... 2001). All these property rights and juridical facts are registered and amended in accordance with legally certified contracts, court decisions, etc. Therefore, all of this information, after they are recorded in register, is considered to be true and full-scale while they are contested in accordance with procedures established by law.

Cadastral data of an immovable property - it is information defining location of the immovable property, natural and economic features of the land, geometric parameters of the buildings and conditions of immovable property usage. Cadastral data may be identified by a land-surveyor - that is a natural person holding a land-surveyor qualification certificated issued by the institution approved by the Government National Land Service under the Ministry of Agriculture (thereinafter - NLS).

Information that is recorded in RE cadastre about the land plot and building cadastre is as follows: unique number of the property, the main objective purpose of use, the area of the land plot, kinds of landed property, special condition of land use, coordinates of the land plot boundaries' turning points, percentage of physical deterioration and completeness of the building, starting and finishing year of the building construction, number of floors of the building, other information established by legal acts (LR nekilnojamojo... 2001).

Unlike the data in the register, cadastral data is less based on juridical documents. Although they are locally identified and prepared during cadastral file formation by a qualified natural person (a landsurveyor), they are verified and approved only in the room of territorial subdivision of NLS.

Aim of research: to analyse mistakes that are being made during RE cadastral data identification performed in Lithuania and systemic drawback of data inspection. Tasks: to provide proposals for improvement of legal acts in order to ensure accuracy of registered information and simplify work for the specialists acting in this process; calculate the need of accurate cadastral measurements and prognosis of perspective works.

Research methods: analysis of scientific articles, legal acts, information collected by NLS and SE Centre of registers; comparison of GIS data created by diverse state organisations and GIS data bases created in other European states. Graphic data is provided using AutoCAD program.

\section{Cadastral data identification of land plots}

From the first sight it may seem that repeated and more accurate geodesic (cadastral) measurements of the operational land plot marked in terrain are not necessary. Any land owner would admit that land plot that was measured 15 years ago, today still retain the same leap, length of boundary lines and area. After all, during Valakų land reform which started back in 1547, land plots were measured with measuring tapes and identification of containers used on the farm were enough to calculate the land area (Gudavičius et al. 2008). However, today in Lithuania, land plots' measurement using more and more accurate geodesic devices is initiated not only by land owners but by the state as well. It shows a certain problem of land cadastral procedures, because land plots that had been tentatively measured in the beginning of land reform must be repeatedly measured with the help of geodesic tools.

It has to be noted, that measurement order of land plots had raised many discussions at its time; some specialists offered to establish compulsory geodesic measurements in all cases. The outcome of tentative measurements is recent arguments among neighbours regarding land, namely due to measurement methods of land plots, disagreement of systems and preparation of inaccurate documents. Illustrating a period of several first land reform actions in countryside, P. Aleknavičius (Aleknavičius 2001a) indicated that land plots, restoring their ownership were marked with temporal landmarks and in cartographic plans their area was calculated with permitted accuracy. An extreme accuracy is not necessary to measure agricultural land and forests in countryside, besides, all land owners were present while marking boundaries of their land plots and know their location. Land plot plans prepared according to tentative measurements should be later updated when land for agriculture or forestry will be rearranged or transferred to other persons. According to procedures established by legal acts, when the same land plot is repeatedly measured, plot boundaries marked in the location shall not be changed and determined difference of land plot area, which does not exceed allowed measurement accuracy, state or land ownershall not receive any remuneration. Therefore, there was no signification for outright 
measurement of artificially separated areas with accurate geodesic devices, because due to intense formation of farms and land market procedures most land plots would be rearranged in the course of time, i. e. would be connected, divided, marked of, etc., so their area would change anyways and fixed landmarks would be destroyed by land owners themselves while working the land. Moreover, if land plots had been outright measured using geodesic devices, prices of land reform works would have doubled and the process would have significantly lingered, as at that time in Lithuania there were few specialists able to perform such kind of work (Aleknavičius 2001a).

Currently there is a sufficient number of land-surveyors in our country as well as higher requirements set for land plot marking on a real estate cadastral map. During the researches the following relevant questions were analysed: how land plot cadastral measurements have been performed currently, what the accuracy of the measurements is, why errors appear and who has to take responsibility for them, what problems need to be solved in order to improve the quality of land cadastral works.

Regulations of Real Property Cadastre of the Republic of Lithuania (LR Vyriausybès... 2002) (thereinafter -Regulations of Cadastre) indicate that a land-surveyor who performs land plot cadastral measurements must follow old landmarks existent in the location and land plot boundaries between boundaries' turning points including them, which border with natural outline must compose one close outline according to which coordinates of boundaries turning points the land plot area shall be calculated. Land plot area calculated after immovable property cadastral data was determined, performing cadastral measurements of the same boundaries using more accurate measures than before, may differ from RE register registered land plot area or projected in territorial planning document yet not registered in RE register land plot area with a area bias of not more than maximum allowable (marginal), indicated in Regulations of Cadastre Appendix 1. That means that land-surveyor, e. g. measuring a 10 ha land plot in a countryside following the landmarks and old cartographic material made in 1:10000 scale, may change the area and add or deduct a 0,3794 ha part of land plot from the land owner. Measuring an 8 ha land plot under the same conditions, permissible maximum error is 0,2828 ha. Maximum error depends on measured land plot and on the available tentative plan (Formula 1). Calculations by different cartographic material shows, that the surveyor has the ability, depending on the required amount of error, choose the type of material by which measure the land.

$$
K \sqrt{P} \text {, }
$$

where: $P$ - area of measured land plot; $K$ - error ratio depending on tentative plan scale, available cartographic material and area of measured land plot.

$0.12 \sqrt{P}=0.12 \sqrt{10}=0.12 \times 3.1622=0.3794$ ha; (other cartographic material Scale 1:10000);

$0.10 \sqrt{P}=0.10 \sqrt{8}=0.10 \times 2.8284=0.2828$ ha (other cartographic material Scale 1:10000);

$0.10 \sqrt{P}=0.10 \sqrt{10}=0.10 \times 3.1622=0.3163$ ha (other cartographic material Scale 1:5000);

$0.08 \sqrt{P}=0.10 \sqrt{8}=0.08 \times 2.8284=0.2263$ ha (other cartographic material Scale 1:5000);

$0.08 \sqrt{P}=0.08 \sqrt{10}=0.08 \times 3.1622=0.2530$ ha (orthophotographic map Scale 1:10000);

$0.08 \sqrt{P}=0.08 \sqrt{8}=0.08 \times 2.8284=0.2263$ ha $($ orthophotographic map Scale 1:10000);

$0.06 \sqrt{P}=0.06 \sqrt{10}=0.06 \times 3.1622=0.1898$ ha (orthophotographic map Scale 1:5000);

$0.06 \sqrt{P}=0.06 \sqrt{8}=0.06 \times 2.8284=0.1697$ ha (orthophotographic map Scale 1:5000).

In cases when cadastral measurements determine that difference in area is bigger than defined in Appendix 1 of Regulations of Cadastre and (or) boundaries (configuration) of land plot does not match the boundaries (configuration) of land plot projected in territorial planning document, the contractor shall inform the client and NLS territorial subdivision according to the location of the land plot in written. The land-surveyor must provide NLS division with the drawing of the setting and indicate projected and actually usable boundaries of the land plot in territorial planning document. NLS division within 30 days analyses settlement documents of marked and neighbouring land plots and other the cartographic material, defines the reasons of difference of land plot and (or) land plot boundaries' (configuration) and writes conclusion regarding specification of land plot boundaries in the terrain and (or) the necessity of land plot boundaries and area specifications in territorial planning document (LR žemès... 2003).

Such order enables to make a conclusion that land owner, without infringing legal acts, may legalise a bigger land plot than he is entitled to on account of the state. In order to receive an increased land plot without violating permissible errors and following 
administrational procedures, it is possible to either correct boundaries in the terrain or revise primary documents. In practice it is done by usually changing line lengths and moving back or forward the boundaries of the plot, for instance, to or away from the stable objects (roads, ditches) (Figs 1, 2).

Cadastral measurements of real estate objects and cadastral data collection and specification rules indicate that cadastral measurements are performed according to territorial planning detail and special plans or land plans which are arranged using topographic, geodesic and other cartographic material. Therefore, surveyors tend to protect the correctness of their measurements according to a legal act which is more favourable for them in an appropriate situation - in one case it is based on landmarks, in other - on the plan of land plot. Having viewed plots registered in RE cadastre in the orthophotographic plans (Figs 3,4) uneven boundaries are clearly visible in those places where the boundaries should align.

It is also obvious that boundaries were measured and registered not according to the actual use of land. Hedged part of the land plot is bigger than it belongs to the land owner according to his primary documents (where area is indicated) therefore, surveyor performing cadastral measurements "attracts" the plot area to the maximum admissibility with bigger space for exploitation in the terrain. In urban territories, such intervening parts of land have currently been more and more often redeemed and connected to nearby usable plot with the help of territorial planning documents. However, such actions are taken by the land owners only when specialists of NLS divisions, after they perform state control of land use (LR Vyriausybės... 1994), indicate in the inspection act that land owner had wilfully occupied state land and infringed Article 45 part 1 of the Code of Administrative infringements of the Republic of Lithuania (LR administracinių... 1985).

A change in line lengths - disagreements before geodesic measurements and after them - is a big problem not only due to possibility to influence the general area of the plot but also due to rising arguments between land owners of adjacent plots. Today, there are no legal regulations for an allowable error while specifying cadastral data, remeasuring previously settled and registered line lengths of the land plots with geodesic tools.

In his educational book about geodesy A. Antanavičius (2007) says that formerly lines of land plots were supposed to be measured with 20-50 meters long steel tapes or tape-lines. Before arranging a plan of a land plot, lines in the location were twice measured following the required measurement accuracy.
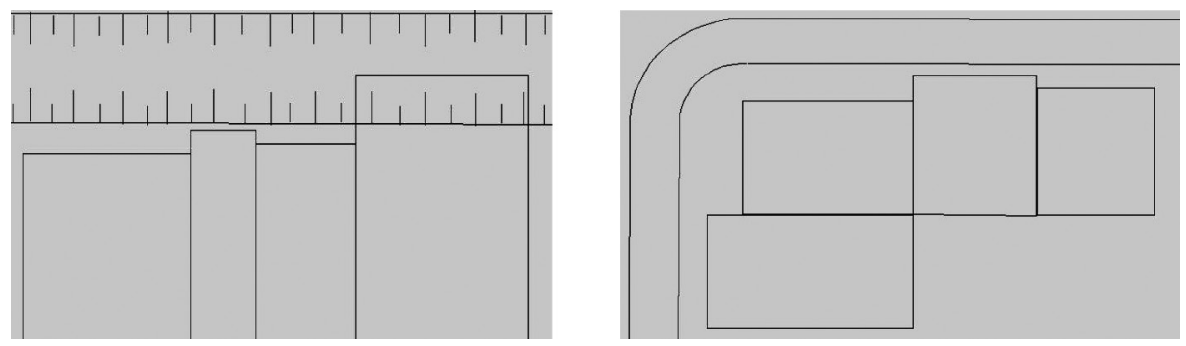

Figs 1, 2. Graphic illustration of uneven geodesic measurements of land plots
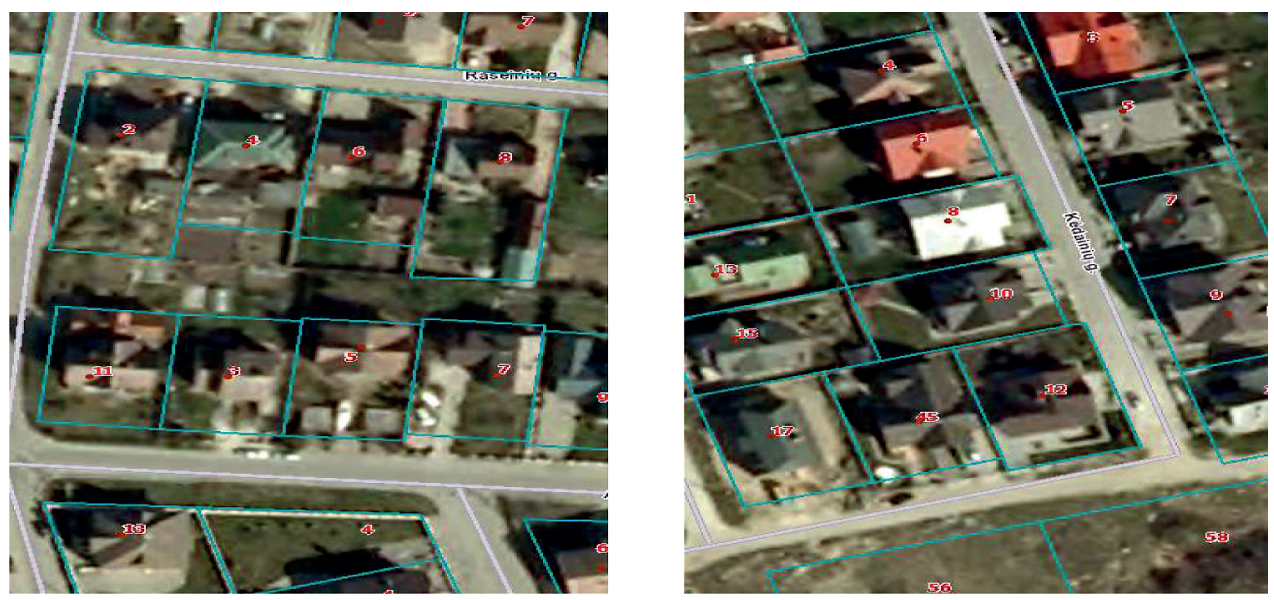

Figs 3, 4. Plot boundaries registered in SE Center of Registers data base 
Measurement accuracy is valued under relative error $f_{s}$ (Formula 2):

$$
f_{s}=\frac{\Delta d}{d},
$$

where: $f s$ - relative error; $\Delta d$ difference between two measurements; $d$-length of the line.

When measurement conditions were good, relative error was supposed to be $1 / 3000$, when average conditions $-1 / 2000$ and bad $-1 / 1000$. If impermissible error (higher value) occurred, the line had to be repeatedly measured.

In geodesy various dimensions (angles, lengths, etc.) are constantly measured. Due to diverse natural, physical and mechanical conditions, results of the measurements may not be absolutely accurate. They always are irregular. Error theory depicts those exact irregularities. Errors may be classified into large, systemic (variable, invariable), random, etc. (James A. Coan 2013). However, all applied formulas are used to find the value and possible deviation of newly measured object. Analysing the situation, it is beside the purpose to apply those formulae, when we have previously measured line and repeated measurement is performed using currently more accurate tools. As arithmetic medium may be calculated only when conditions for measurement are the same and average square errors are calculated when several measurements are performed in respective time in order to find possible deviation of a fixed dimension.

In practice, geodesists who perform cadastral measurements of land plots using more accurate tools are certain that it would be more purposeful to find a limit not to be crossed, as it is done when area is measured (permissible deviation of area). However, to what extent is it purposeful? If, in the location, the line was obviously measured incorrectly, today, under the certain formulae the line would have to be measured incorrectly again because the formulae does not allow to measure the exact dimensions. Of course, suitable formulae would help to solve arguable problems when adjacent plots to be remeasured cross, when lengths of both lines do not correspond to initial documents and the situation of the location does not allow to decide the limit between the measured land plots. When determining similar situations, specialists follow the Article 4.45 of the Civil Code (LR civilinis kodeksas 2000) which states that if land plot owners disagree regarding arguable limits of the plots and they are not clearly provided in the documents, limits are determined by court in view of the documents, limits of actually owned plot and other evidence. If the limits are impossible to be determined, parts of equal size of arguable plot must be attached to each land plot, however none of this way newly formed plot must be different in area from the existing and legally endorsed plot.

Another very relevant problem is when situations illustrated in the plan do not correspond to explication of landed property filled in cadastral data tables as well as to determination and elimination of special conditions of land usage.

Unit 32.1.3 of Regulations of Cadastre indicates that factual landed property cartographed during cadastral measurements in the location are: built-up territorial border (land occupied with buildings, yards and fields, or other land used for direct building exploitation), transport engineering buildings (communications), other roads (not formed as buildings), border of water body and hydrographical net, forest line, line of ploughland, gardens, meadows and natural greenlands and otherland that is composed from trees and bush plantations, swamp line, affected land areas of exploitable and exploited mineral quarries, peatbogs and dumps. However, surveyors, following the state accounting rules of Land (LR Žemès... 2002), often distort the accuracy of cadastral data. Unit 14.1 of the rules indicates that minimal land area which is accounted as a separate landed property is: 0,10 ha for forests, swamps, tree and bush plantations; 0,04 ha for other landed property. However, land plots near buildings and residential land may be accounted as built-up territory without excluding separate landed property, if land plot is not larger than 0,15 ha; Amateur garden plot valid as residential land is accounted as built-up territory and in other cases - as a garden. Therefore, while measuring garden plots or plots for residential territory, surveyors no longer detail cadastral data and attribute all to built-up territory, however, according to the cartographed situation in the plan it is obvious that land plot includes water bodies, treecovered areas, etc. This way, we only store approximate data in geographic data bases, although technical opportunities allow to have them very accurate. It is understandable, that such minor data changes the most in the course of time, however, it would be preferable to see at least similarity but not an absolute mismatch when comparing plan and cadastral data tables.

Article 22 of the Law on Land of the Republic of Lithuania (LR žemès... 2011) says that special conditions of land exploitation (LR Vyriausybès... 1992) are determined by law and resolutions of Government. 
Special conditions of land exploitation applied to a particular land plot are entered into RE cadastre and Register of RE by registering settled new (in territories where land plots were not settled before the documents of territorial planning were confirmed) land plots according to the territorial planning documents. When, after new territorial planning document or its specification is confirmed, additional special conditions of land exploitation are to be applied to a land plot (or a part of it) registered in Real Estate registry or previously applied conditions are to be withdrawn, the organiser of territorial planning document or its specification within one month after the confirmation of the territorial planning document or its specification has to inform the landlord of the plot or the user of state or municipal land in writing, indicating particular applicable or revocable special conditions of land exploitation and, in accordance with the order determined by Law on Real Estate Cadastre and Law on Real Estate Registry providea report to the keeper of the Real Estate Cadastre and Real Estate Registry, based on which he makes a certain marking in the registry record of the land plot on the applicable or revocable special conditions of the land exploitation.

According to valid legal acts, when a surveyor prepares or specifies cadastral data of the land plot he must follow territorial planning documents and is not able to determine or eliminate new special conditions for the land exploitation by himself. In practice, it is rather difficult to follow such regulations, and only recently this problem has been ventilated. Surveyors are accustomed not only to determining or eliminating special conditions for land exploitation but servitudes as well. After many public discussions and NLS explanations surveyors realised that they are not allowed to determine servitudes wilfully. However, a more difficult situation is regarding restrictions of land exploitation. Frequently, while measuring the land plot surveyor finds a water-supply or a connection line there. However, he cannot determine safety zones for those engineering networks as the territorial planning document had not been prepared when those networks were constructed. The same situation when measured land plot includes electricity poles without wires. Virtually, these engineering (infrastructural) buildings no longer function under their direct purpose, however, according to the planning project of land reform, there is a determined safety zone for a land plot. A surveyor is not able to eliminate such restriction as long as the territorial planning document is prepared. Preparation of territorial planning document is not only pricey for the owner of land but also is a long process. Therefore, it is necessary to simplify the correction of special conditions for land exploitation to specify cadastral data of the land plot. A solution to enable the surveyor to complete the process: correction of each cadastral data should be based on certain information. Therefore, a document based on which the surveyor made a change of data should be included in the cadastral measurement file. Certain institutions are responsible for each certain engineering infrastructure which regulates topographic maps composed by geodesists. Topographic map is a map which illustrates topographic natural and anthropogenic objects on the surface of land (LR geodezijos... 2001). Wherefore, if the surveyor specifies cadastral measurements of the land plot and finds that factual situation does not correspond to the special conditions for land exploitation determined by the old (for example, prepared up to year 2000) territorial planning document, he would be able to prepare a topographic map outright and match it with all appropriate institutions. Preparation of a topographic map will cost significantly less for the owner than preparation of territorial planning document and the period needed for this process is obviously shorter. After that, NLS territorial division having matched the cadastral measurement fileand following the valid topographic map will be able to make an administrational decision and specify special conditions for land exploitation.

Practicians face with many small yet significant mistakes that are caused by the specialists themselves. For example, there is an attitude that while measuring land plot borders it is necessary to match them with the borders of the adjacent plot that were determined by earlier measurement and that are considered to be correct as long as the court contests them. Due to such requirement land plots are being "stucktogether" despite the fact weather previous measurement were correct or not. The decision of the specialist who checked the measurement should not be taken for granted as it happens that measured land plot is in the middle of the field and then after the measurement it emerges that land plots located near the stable elements in the location do not fit in or the configuration of the plot must be changed. Therefore, while measuring plots surveyors are recommended to look for attachment to stable elements in the location, check on the plans of the adjacent plots and, naturally, not to be afraid to initiate the correction of the plots that were incorrectly measured.

Measurement of land plots may not be imagined without relating them to the geodesic background. This 
procedure contains small shades that the land owners know a little about, however these misunderstandings may cause problems and arguments leading to judicial process. Unit 31.1.2.2.2 of the Regulation of Cadastre states that land plots to be measured that border with previously measured land plots using geodesic tools in the state coordinate system, general difference of landmark coordinations in the cities must not be more than $0.1 \mathrm{~m}$, in other territories not more than $0.3 \mathrm{~m}$. Units $30-40$ of the rules of Real estate object cadastral measurements and cadastral data collection and specification elaborate geodesic deviations that were not allowed to be exceeded by the surveyors while performing cadastral measurements of the land plots. Recently, the greatest contradictions have occurred due to attempt to confront plots measured in different system of coordinates. Previously, measurements were inaccurate due to technical devices and methods. Consequently, there were requirements such as: while performing cadastral measurement of land plot borders at least two landmarks of the adjacent land plot had to be related to national geodesic network or (in the cities, towns, built-up territory in the village) with the local geodesic network which is connected to the national network (LKS-94); Relation to be made by planimetric networks, maximum length of related line for agricultural and forestry land plots $-5 \mathrm{~km}$; performing cadastral measurements of land plots by close circle corresponding to the perimeter of the land lot, permissible nonrelation of angles $l^{\prime} \sqrt{n}$, relative deviation of the circle not higher than $1 / N \leq 1 / 3500$. Accuracy of the measurement must ensure the accuracy of area determination $m_{p} / P=1 / 1000$; performing cadastral measurements in polar way together with auditorial measurements it is necessary to level and value average square deviation of each boundary turning point. Deviations must not exceed $4 \mathrm{~cm}$. Having fulfilled the aforementioned conditions, relative accuracy of area determination may be reached (formula 3) (LR Vyriausybès... 2002):

$$
\frac{m_{p}}{P}=\frac{1}{1000} .
$$

The need of accuracy rises together with the improvement of technologies. Administrational distribution of locations changes with the time, therefore, previously permissible mismatch between the same plots (in countryside) was $0.3 \mathrm{~m}$, and now (when terrain is attached to city territory) the mismatch allowed is only $0.1 \mathrm{~m}$. As a result, not only deviations of previously measured plots but also the changes of today's administration make the land plots be considered incorrectly measured.

\section{Supervision of activities}

In February 1919, in the beginning of land management activities in the territory of independent Lithuania the Department of Land Management was established. It consisted of one manager and 5 surveyors. The number of specialists grew together with the increasing importance of land activities: there were 62 specialists in 1920, 203 in 1925, 242 in 1937 (Bačelis 2008). The organisation changed its name many times (Department of Land Management under the Ministry of Agriculture, National Land Service, etc.) as well as its functions (Aleknavičius 2001b). The number of specialists in the organisation and their activities changed, too. Today National Land Service under the Ministry of Agriculture is an institution of the Republic of Lithuania which implements national policy in the fields of cadastre, accounting, geodesy, cartography, preparation of national georeferencedspatial information collection and creation of spatial information infrastructure of Lithuania. This institution alone employs around 900 specialists and around 2000 qualified surveyors, 900 geodesists and around 1900 land planners-delineators are entitled to work in the fields (NLS information).

The volume of performed activities is large, therefore, many good specialists are required in the process of management (inspection) as well as in the generation of performed activities (in the fields). The main specialists capable to work in that area are equipped in Aleksandras Stulginskis and Vilnius Gediminas Technical universities as well as Kaunas, Klaipeda and other colleges.

Quality of performed activities may be evaluated under the errors the specialists make, which leads to client dissatisfaction with occasional judicial processes. The specialists who performed the inspection of the activities, under the obligatory procedure, must appear in the court, too. The correctness of cadastral measurements of land plots is inspected by NLS specialists who cope with huge load of work and due to the lack of specialists not all planned control procedures of work are fully completed. During the year 2011 the specialists of NLS territorial divisions accepted 105963 files of cadastral measurements of land plots 31264 of which were found to be deficient and due to that reason the files could not be submitted for the registration in the RE cadastre and 1626 files where checked in the the field. Territorial divisions that performed most activities in cadastral data inspection are listed in the below statistical tables (Tables 1-3). 
Statistical data shows that NLS territorial divisions are submitted with up to $29.5 \%$ improperly prepared files of cadastral measurement and only $1.53 \%$ of files that are submitted to the divisions were inspected in the field. Obviously, quality of the performed activities needs to be improved. Surveyors who irresponsibly submit files of cadastral measurements to the territorial divisions waste the inspecting specialists' time and land owners are provided with a non qualitative product which they pay money for. Since, there is such a big number of files that need to be corrected and only checking them in the office it is obligatory to increase a number of inspections in the terrain. NLS does not have information on how many files checked in the terrain were found deficient, however, presumably most of inspection acts were made containing remarks and drawbacks.

It is also necessary to increase a number of specialists in territorial divisions which receive most files as checking the files only in the office is a huge load of work and it's physically impossible to devote time for checking data in the field. There should be a system where each survey or together with his qualification certificate would have information on the number of errors determined in percents of all the files submitted to the division. In such case, there would be a possibility to assess their skills and to suspend activity of the certificate, if the measurements are not of the good quality. Today, the way to suspend such activity is possible only by formally informing against the surveyor, yet this spotfires "co-worker" behaviour. Surveyors who want to acquire the qualification certificate required for that kind of work must be demanded higher requirements - to improve the period of practical experience.

\section{Data collection and mapping using geographical information system}

On March 14, 2007 the European Parliament and the European Council agreed and approved the Directive 2007/2/EC of the establishment of the Infrastructure for Spatial (geographically oriented) Information in the European Community, also known as INSPIRE. This directive aims to make the spatial data (such as orthophotographic images, air and water pollution and meteorological data, digital map objects: roads, rivers, administrative boundaries, land covering, etc.) of European Union territory (hereinafter - EU) mutually compatible and easily accessible. Since the middle of 2005 the project "Development of Geographic Information Infrastructure in Lithuania"(hereinafter - DGIIL) allowed Lithuania to become one of the European leaders
Table 1. Territorial NLS divisions which regularized biggest number of cadastral measurement files of land plots in 2011

\begin{tabular}{|l|c|c|c|}
\hline \multicolumn{1}{|c|}{$\begin{array}{c}\text { Territorial } \\
\text { division }\end{array}$} & $\begin{array}{c}\text { Files } \\
\text { accepted }\end{array}$ & $\begin{array}{c}\text { Files } \\
\text { denied }\end{array}$ & $\begin{array}{c}\text { Files } \\
\text { checked in } \\
\text { the field }\end{array}$ \\
\hline Vilnius district & 5230 & 3752 & 15 \\
\hline Klaipėda district & 4634 & 1859 & 33 \\
\hline Vilnius city & 4572 & 2623 & 114 \\
\hline Alytus & 3394 & 1974 & 15 \\
\hline Trakai and Elektrènai & 3367 & 1551 & 33 \\
\hline Šiauliai & 3283 & 351 & 7 \\
\hline Kaunas district & 3110 & 3312 & 46 \\
\hline Panevėžys & 2816 & 1019 & 31 \\
\hline Tauragė ir Pagėgiai & 2071 & 573 & 0 \\
\hline $\begin{array}{l}\text { Marijampolé, Kazlų } \\
\text { Rūda, Kalvarija }\end{array}$ & 2010 & 880 & 423 \\
\hline
\end{tabular}

Source: National Land Service.

Table 2. Territorial NLS divisions which regularized biggest number of improperly prepared cadastral files of land plots in 2011

\begin{tabular}{|l|c|c|c|}
\hline Territorial division & $\begin{array}{c}\text { Files } \\
\text { accepted }\end{array}$ & $\begin{array}{c}\text { Files } \\
\text { denied }\end{array}$ & $\begin{array}{c}\text { Files } \\
\text { checked in } \\
\text { the field }\end{array}$ \\
\hline Vilnius district & 5230 & 3752 & 15 \\
\hline Kaunas district & 3110 & 3312 & 46 \\
\hline Vilnius city & 4572 & 2623 & 114 \\
\hline $\begin{array}{l}\text { Lazdijai, } \\
\text { Druskininkai }\end{array}$ & 1832 & 2037 & 83 \\
\hline Alytus & 3394 & 1974 & 15 \\
\hline Klaipeda district & 4634 & 1859 & 33 \\
\hline Trakai and Elektrènai & 3367 & 1551 & 33 \\
\hline Panevėžys & 2816 & 1019 & 31 \\
\hline Mažeikiai & 1811 & 981 & 447 \\
\hline $\begin{array}{l}\text { Marijampolé, Kazlų } \\
\text { Rūda, Kalvarija }\end{array}$ & 2010 & 880 & 423 \\
\hline
\end{tabular}

Source: National Land Service.

Table 3. Territorial NLS divisions which inspected biggest number of cadastral measurements of land plots in terrain in 2011

\begin{tabular}{|l|c|c|c|}
\hline Territorial division & $\begin{array}{c}\text { Files } \\
\text { accepted }\end{array}$ & $\begin{array}{c}\text { Files } \\
\text { denied }\end{array}$ & $\begin{array}{c}\text { Files } \\
\text { checked in } \\
\text { the field }\end{array}$ \\
\hline Mažeikiai & 1811 & 981 & 447 \\
\hline $\begin{array}{l}\text { Marijampolè, Kazlų } \\
\text { Rūda, Kalvarija }\end{array}$ & 2010 & 880 & 423 \\
\hline Vilnius city & 4572 & 2623 & 114 \\
\hline $\begin{array}{l}\text { Lazdijai, } \\
\text { Druskininkai }\end{array}$ & 1832 & 2037 & 83 \\
\hline Šakiai & 855 & 110 & 58 \\
\hline Vilkaviškis & 808 & 366 & 55 \\
\hline Kaunas district & 3110 & 3312 & 46 \\
\hline Širvintos & 873 & 597 & 41 \\
\hline Plungė and Rietavas & 1479 & 224 & 37 \\
\hline Klaipeda district & 4634 & 1859 & 33 \\
\hline
\end{tabular}

Source: National Land Service. 
in the development of a unified system of Community for spatial information. It is expected that the Directive INSPIRE will increase the efficiency of environment, in the first place, as well as other related sectors, such as transport, energy or agricultural policy management by providing the opportunity to effectively make decisions using reliable, high-quality and mutually agreed data in the EU countries (Lietuvos geografinès... 2007).

Spatial (geographic) data is stored in databases and made available to the public in the form of maps (analogical or digital). Some data is available for free, to view other information the user's identity or even a monetary reward is necessary. State Enterprise Centre of Registers is creating a new digital mapping website ("REGIA"), which allows to place the boundaries of the land plots registered in RE cadastre on the latest version of orthophotographic map, as well as the boundaries of protected areas, objects of cultural and natural heritage in some municipalities and valid territorial planning documents (Fig. 5). In the future, the website is planned to be focused more on the needs of municipal employees and businesspeople.

When you sign in the main website of SECentre of Registers you can see much more important data. Despite the land borders and the latest orthophoto map you can also findt he layer of administrative boundaries, engineering networks, maps of real property values (Fig. 6). To identify the certain objects and receive registry information, you need to pay money. This database is mainly used by surveyors, who
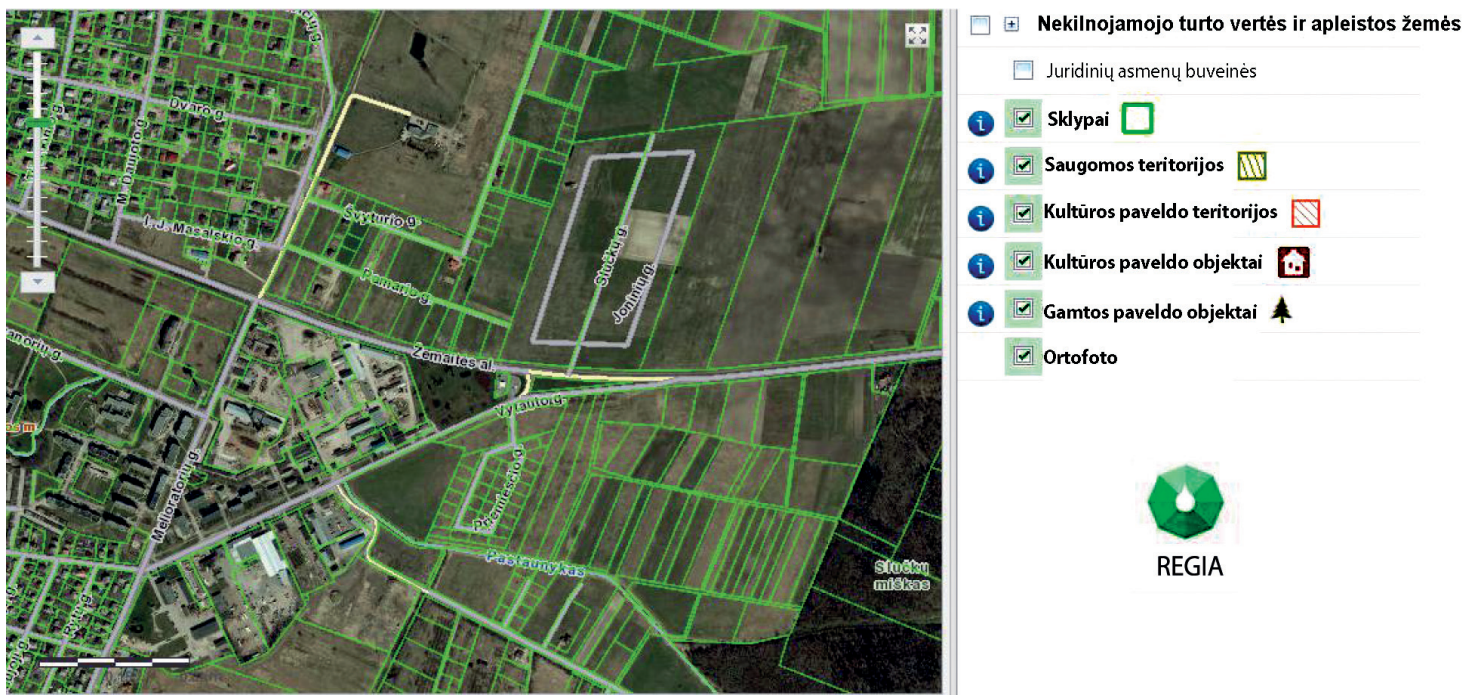

Fig. 5. View of the digital map "REGIA"

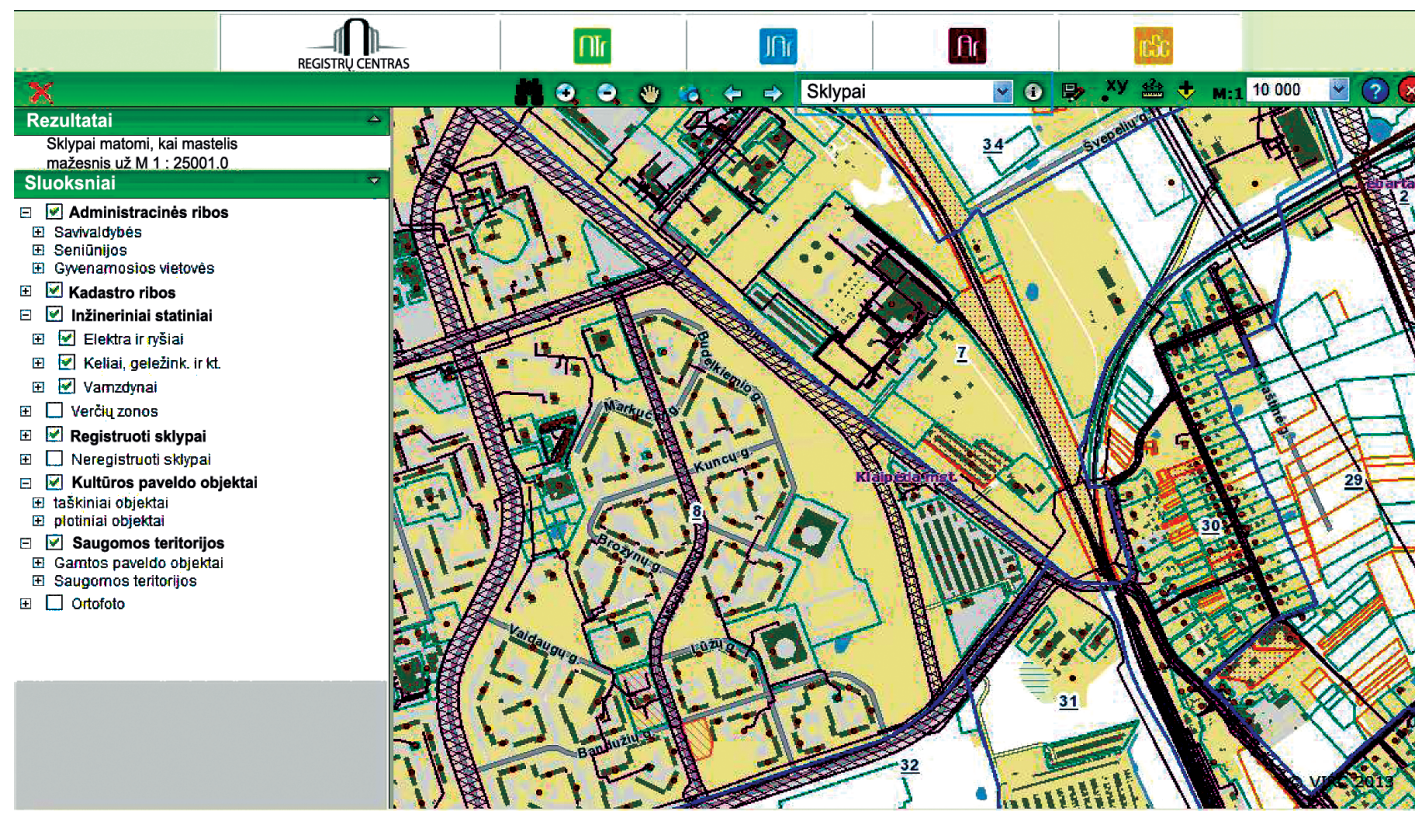

Fig. 6. Cadastral data map of SE Center of Registers 
can see the land owners and landmark coordinations of geodesically measured land plots.

The most comprehensive collection of spatial data is now available on website "geoportal.lt" (Fig. 7). The goal of "Geoportal.lt" is to make centralized access to data users to data collections and their metadata created by state registries, registries' managers, state and local government authorities and other persons. It provides users with electronic services of search, preview, download, transformation of spatial data collections. Lithuanian spatial information portal was created in 2008 under the project "Development of Lithuanian Geographic Information Infrastructure" funded by the Republic of Lithuania and the European Union. Lithuanian spatial information portal is managed by the State Enterprise "GIS-Center" and the manager of the portal is NLS (Lietuvos erdvinès... 2013).

Amongst the many layers of data, this website contains such information that other sites cannot provide. Because NLS is the controller of the a digital map, the presented data here is not only cadastral information on land plots, but also information about the composition of the soil, drainage facilities, spatial data collection of special conditions on land exploitation, abandoned land, land productivity, etc.

The progress of this area varies in each country. For example, in Finland all cadastral data is digitized, comprehensive yet scattered across many registers. Databases are managed by national authorities and the individual municipalities. It collects data not only about preserved buildings or land rent, but also it is a relevant finding for hunters and fishermen on the forests and water bodies they are interested in, while in Hungary, main focus is on agriculture (Rummukainen 2009).

Many authors argue, that the most advanced in this process are Belgium, the Netherlands, Finland and Lithuania, while the worst performer seems France and Turkey (Yavuz 2005; Wilkowski 2006). Turkish cadastral system was started up since 1924 and the structure of that institution to this day has not changed since 1936. About 20 percent of the cadastral maps has not yet been associated with the coordinate system. Therefore, the main task is to paper maps finally digitize and link them to the coordinate system. It also raises the need for local professionals to transform all data into a single national system of coordinates (Poyraz 2002).

The overall goal for the states is to refine their GIS up to the principles described in the program "Cadastre 2014". Key objectives are: completely register ownership rights and restrictions to real estate, combine cadastral maps and registers into a single system, digitize all the data and make it suitable for long-term simulation, to aim for private and public sector to work together for a single purpose, gain official and tangible benefit from the accomplished activities(Kaufmann 2002).

Compared to other countries, the progress of Lithuania in this field is obviously beyond many states due to its professionalism and the work carried out, and services available to users meet the tasks raised by international agreements in full.

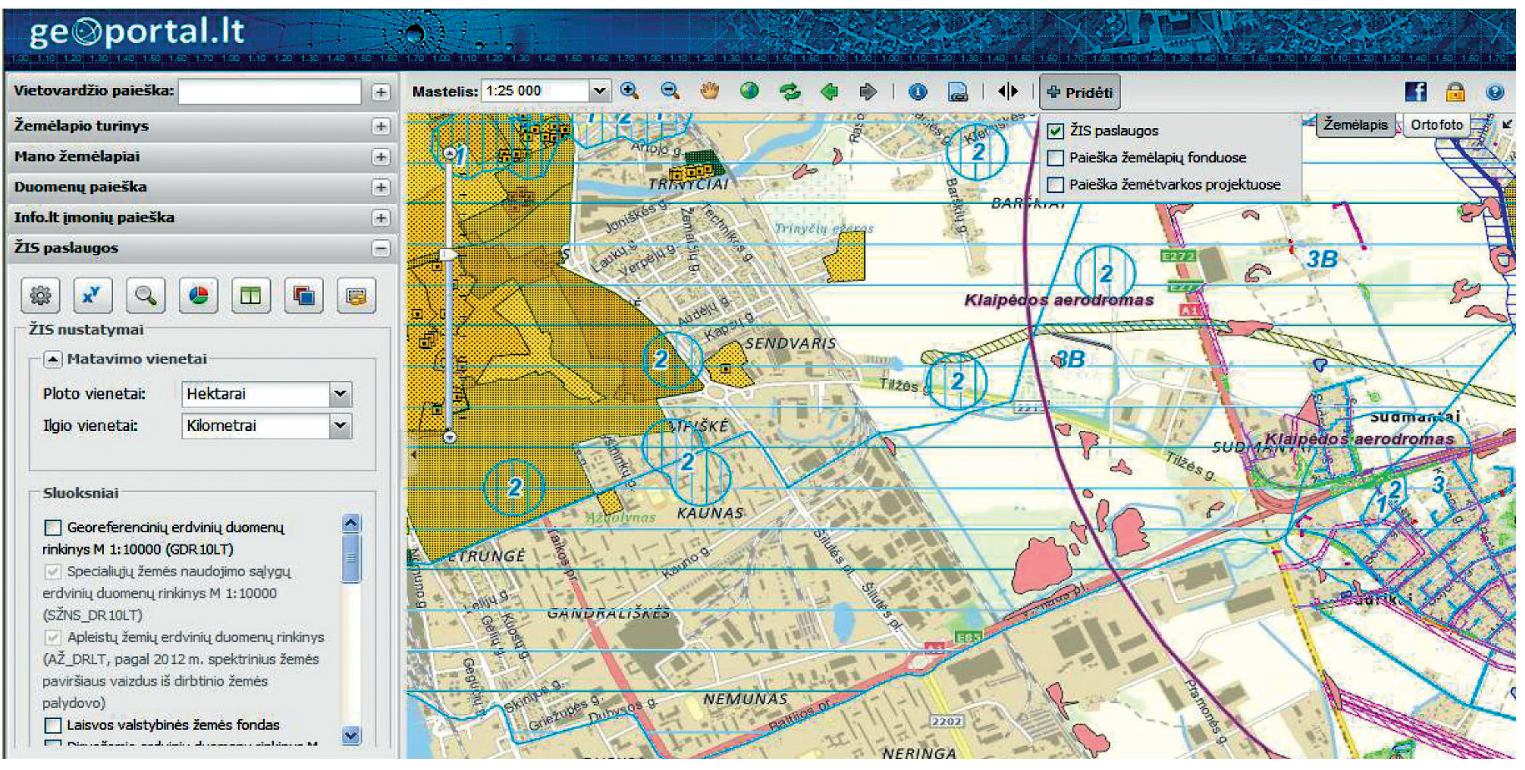

Fig. 7. Lithuanian portal of spatial information "Geoportal" 


\section{Further work forecast in the territory of Lithuania}

The statistics of SE Centre of Registers and NLS may help to perform various tests and forecast the trends of further actions. The analysis of registered data on land plots regularized under preliminary or cadastral measurements enables to calculate the percentage of the total number of land plots measured using accurate surveying instruments and follow this percentage within the last 20 years (Table 4).

Since 1993, the number of preliminary measured plots rapidly increased due to the land reform and land plots formed during that process, which were not supposed to be measured using geodetic devices. Due to declining volume of reform activities, the decrease of such sites has been noticed since 2005,besides, there has been an increase of need of cadastral measurement for legal decisions (to convert land plots or dispose the property).

According to the estimated percent (Table 4), there has been about 33 percent of the preliminary land plots accurately measured in Lithuania in 2013. In order to have a clearer view of how performed measurement work is distributed throughout the territory of Lithuania it is advisable to depict them graphically

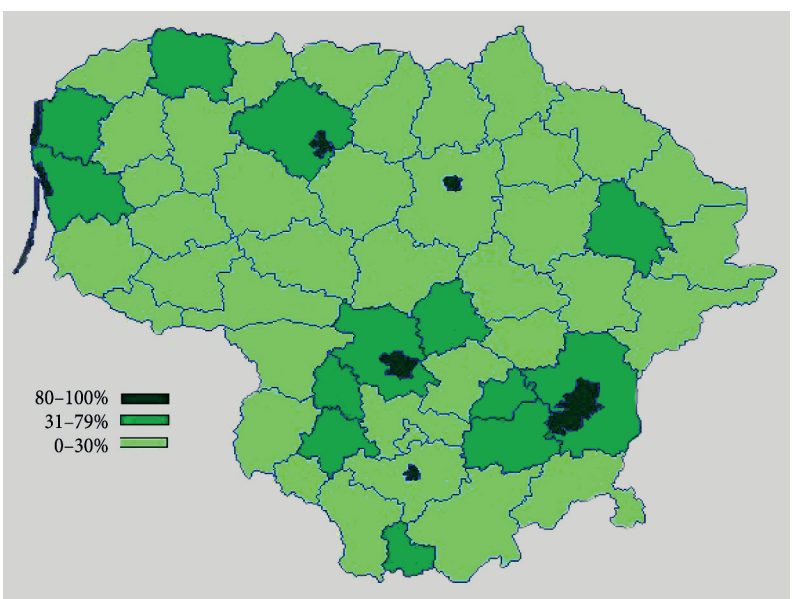

Fig. 8. Percentage of land plots measured with geodesic devices of all the registered plots
(Fig. 8). It is clear that most of the measurements have been performed around the areas of major cities, and where the land reform has been completed or is coming to an end. The highest percentage of registered land plots, measured with geodesic devices are: in Alytus 99.40\%, in Kaunas - 98.20\%, in Klaipeda - 91.13\% in Panevėžys - 90.47\%, in Palanga - 91.03\%. Lowest percentage of registered land plots, measured with geodesic instruments are: in Skuodas district - 12.87\%, Pasvalys district $-13.54 \%$, Varèna district $-14.69 \%$, Lazdijai district $-16.48 \%$, Raseiniai district $-16.76 \%$.

It is impossible to say exact period of time to accurately measure all the land plots, while the completion of land reform is pending, and without knowing what legal acts will be accepted in the upcoming year, and how cadastral measurements of the plots will be encouraged. Given the fact that about 30 percent of the formed plots have been measured within 20 years, supposedly, it will take another 40 years to complete this process. Since there are areas in Lithuania where the process is coming to an end, a more detailed and mostly likely prognosis might be made according to the statistics of SE Centre of Registers and NLS (Table 5).

In order to calculate the time during which it is expected to clarify the preliminary measurements, it is necessary to know the extent of preliminary measurements of the observed decrease each year. Then from this number is divided the number of remaining preliminary land plots (Formula 4):

$$
\begin{aligned}
& \mathrm{B} / 5=\mathrm{C} ; \mathrm{A} / \mathrm{C}=\mathrm{D}, \\
& 652 / 5=130 ; 806 / 130=6 .
\end{aligned}
$$

The calculations show that the process within the preliminary land plots are expected to be remeasured will take quite a long time. In areas where the percentage ratio between the preliminary and cadastral measurements is fairly high, the measurement of preliminary land plots is rather slow. According to the analyzed number of inspections of cadastral files of land plots performed by NLS territorial divisions and downtrend of preliminary measured plots, it can be

Table 4. Analysis of registered and within the period of 1993-2013

\begin{tabular}{|l|c|c|c|c|c|c|}
\hline \multicolumn{1}{|c|}{ Year (data record date) } & 1993 & 1997 & 2001 & 2005 & 2009 & 2013 \\
\hline Land plots with preliminary measurements & 100000 & 592000 & 996000 & 1625000 & 1529000 & 1421000 \\
\hline Land plots with accurate measurements & 22000 & 175000 & 269000 & 363000 & 471000 & 700000 \\
\hline Total registered plots & 122000 & 767000 & 1265000 & 1988000 & 2000000 & 2121000 \\
\hline $\begin{array}{l}\text { Percentage of land plots measured with } \\
\text { geodesic tools of the total number of } \\
\text { registered plots }\end{array}$ & 18.03 & 22.81 & 21.26 & 18.26 & 23.55 & 33.00 \\
\hline
\end{tabular}

Source: SE Centre of Registers. 
Table 5. Volume and perspectives of cadastral measurements of land plots

\begin{tabular}{|l|c|c|c|c|c|}
\hline City & $\begin{array}{c}\text { Number of land } \\
\text { plots (preliminary } \\
\text { measurements) } \\
\text { registered by SE } \\
\text { Centre of Registers } \\
(2013)\end{array}$ & $\begin{array}{c}\text { Number of } \\
\text { decreased } \\
\text { preliminary } \\
\text { land plots } \\
\text { within } \\
2009-2013 \\
{[\mathrm{~A}]}\end{array}$ & $\begin{array}{c}\text { Number of } \\
\text { decreased } \\
\text { preliminary } \\
\text { land plots with } \\
\text { a year }\end{array}$ & $\begin{array}{c}\text { Number of } \\
\text { cadastral } \\
\text { measurement } \\
\text { files regularized } \\
\text { in NLS territorial } \\
\text { division in } \\
2011\end{array}$ & $\begin{array}{c}\text { Forecasted period } \\
\text { (years) within } \\
\text { which all remained } \\
\text { preliminary land plots } \\
\text { in the territory shall be } \\
\text { measured } \\
\text { [D] }\end{array}$ \\
\hline Alytus & 33 & 32 & 6 & 3394 (incl. district) & 6 \\
\hline Kaunas & 631 & 232 & 46 & 1104 & 14 \\
\hline Klaipėda & 806 & 652 & 130 & 490 & 6 \\
\hline Panevėžys & 1222 & 455 & 91 & 2816 (incl. district) & 13 \\
\hline Palanga & 649 & 394 & 78 & 233 & 8 \\
\hline
\end{tabular}

Source: SE Centre of Registers and NLS.

concluded that in these areas NLS divisions are mainly engaged in specification of RE cadastral data.

\section{Conclusions}

1. Identification of the real estate cadastral data and its registration in the national register is an important process in the developed countries, however, this process needs improvement in Lithuania. Data is identified by under qualified surveyors and there is lack of specialists to control their work. Since the number of specialists performing measurement is large enough, their qualification skills need more rigorous evaluation to prevent frequent mistakes.

2. The cadastral measurements of land plots are regulated by a number of requirements established in legal acts. One of the main requirements is to keep the land plot area within permissible limits. Many experts suggest applying admissibility error for line lengths, however, it must be well considered if such criterion does not make measurements complicated. The main unit of measure is the area, and the line lengths are of the second priority, as the owners often dispose of the land area. However, there should be a clearly validated opinion on what is more important when measuring the land - old landmarks under which the land is used, or the territorial planning document which must be followed by the land owner. In practice, these two criteria often do not match and it is difficult to determine whether the plan was prepared incorrectly or the owner of the land has not been operating it under its purpose.

3. The surveyors, during the qualification improvement course, must be explained that their duty is to measure plots but not to form them. In addition, the opinion that NLS takes responsibility for the correctness of the data after it confirms the cadastral file of the land plots, must be changed. The person who performed measurements should always participate in the judicial procedure. This would highlight the importance of the work and work quality would improve.

4. Today, it may be concluded that due to planning (measurement) mistakes made by project authors of land reform it would have been more purposive to perform repetitive (geodesic) cadastral measurements under complex principle, i. e. between permanent natural objects (from road to road, from ditch to forest, etc.). Specialists who inspect measurements should also demand borders of longer distances to be arranged gradually but not "stepline".

5. Collection and presentation of spatial data in Lithuania is developed enough and of high quality. However, it is rather difficult for novice users to select more reliable information and which digital map to use. Naturally, such submitted data as special conditions of the land use areas should not be trusted blindly. It is important to realize that the surveyor who measured the location is able to provide more accurate information, and the development of the interactive maps is based and their work.

6. In Lithuania are left few cities with preliminary measured land plots, however, the remaining measurements in these cities are being performed slowly, and this process is projected to take about another 6-14 years. To speed up this process, in certain cities (densely urbanized areas) must be identified places, where land owners would have to change preliminary measurements under determined period of time.

\section{References}

Aleknavičius, P. 2001a. Ar reikalingi geodeziniai matavimai žemès reformos metu, iš Pirmasis žemès reformos dešimtmetis. Vilnius: Jandrija, 156-163.

Aleknavičius, P. 2001b. Valstybinès žemètvarkos ir geodezijos tarnybos reorganizavimas, iš Pirmasis žemés reformos dešimtmetis. Vilnius: Jandrija, 148-151. 
Antanavičius, A. 2007. Geodezijos pagrindai. Kauno raj.: Akademija 18-21.

Bačelis, Z. 2008. Nepriklausomos Lietuvos 20 metu žemès tvarkymo darbai, iš Lietuvos žemètvarkos istorijos chrestomatija. Vilnius: Jandrija, 263-278.

Bjornsson, C. 2005. Cadastre 2014 - From vision to GIS. COST Office, Denmark.

Cete, M.; Mustafa, H.; Geyman, A. 2010. The Tuskish cadastral information system and lessons learned, Scientific Research and Essays 5(7): 625-633.

Coan, J. A. Understanding Errors in Measurements [online], [cited 21 September 2013]. Available from Internet http:// proceedings.esri.com/library/userconf/survey11/papers/ pap_3529.pdf

Daugherty, K. 2006. Technology for land administration (GIS), improving government administration and services to its citizens, in ITC Lustrum Conference, 2006, Netherlands.

Gasilionis, A.; Kasperavičius, R. 2006. Nekilnojamojo turto administravimas. Vilnius: Rotas.

Gudavičius, E.; Jurginis, J.; Kiaupienè, J.; Mulevičius, L., ir kt. 2008. VI Registrų centras „Nekilnojamojo turto administravimas Lietuvoje XIV-XVIII a., iš Lietuvos žemetvarkos istorijos chrestomatija. Vilnius: Jandrija: 136-154.

Kaufmann, J. 2002. Cadastre 2014: a vision for future cadastre systems, in 1st Congress on Cadastre in the European Union, 15-17 May, 2002, Granada, Spain.

Lietuvos geografinès informacijos infrastruktūros išvystymas. 2007. Informacinis leidinys. VI „GIS-Centras“, Vilnius.

Lietuvos Respublikos administracinių teisès pažeidimų kodeksas, Žin., 1985, Nr. 1-1.

Lietuvos Respublikos civilinis kodeksas, Žin., 2000, Nr. 742262-2013, Nr. 76-3843.

Lietuvos Respublikos geodezijos ir kartografijos įstatymas Nr. IX-415, 2001-06-28. Žin., 2001, Nr. 62-2226.

Lietuvos Respublikos nekilnojamojo turto kadastro įstatymas Nr. VIII-1764, 2000-06-27. Žin., 2000, Nr. 58-1704.

Lietuvos Respublikos nekilnojamo turto registro įstatymas Nr. IX-391, 2001-06-21. Žin., 2001, Nr. 55-1948.

Lietuvos Respublikos Vyriausybès 1992 m. gegužès 12 d. nutarimas Nr. 343. Dèl specialiųjų žemès ir miško naudojimo sąlygu patvirtinimo, Žin., 2012, Nr. 110-5578.
Lietuvos Respublikos Vyriausybės 1994 m. gruodžio 12 d. nutarimas Nr. 1244. Dèl žemès naudojimo valstybinès kontrolès nuostatų patvirtinimo, Žin., 1994, Nr. 95-1864.

Lietuvos Respublikos Vyriausybès $2002 \mathrm{~m}$. balandžio 15 d. nutarimas Nr. 534. Dèl Lietuvos Respublikos nekilnojamojo turto kadastro nuostatų patvirtinimo, Žin., 2002, Nr. 411539.

Lietuvos Respublikos žemès ūkio ministro 2002 m. gruodžio 30d. įsakymas Nr. 522. Dèl nekilnojamojo turto objektų kadastrinių matavimų ir kadastro duomenų surinkimo bei tikslinimo taisyklių, Žin., 2003-02-21, Nr. 18-790.

Lietuvos Respublikos žemès ūkio ministro 2002 m. rugpjūčio 7 d. ísakymas Nr. 302. Dèl žemès valstybinès apskaitos taisyklių patvirtinimo, Žin., 2002, Nr. 80-3472-2012, Nr. 1-21.

Lietuvos Respublikos žemės ịstatymas Nr. XI-1314, 2011-04-12. Žin., 2011, Nr. 49-2369;

Registrų centras [interaktyvus], [2013 m. spalio 11 d.]. Prieiga per internetą: www.kada.lt

Lietuvos erdvinès informacijos portalas [interaktyvus], [2013 m. spalio $12 \mathrm{~d}$. ]. Prieiga per internetą: http://www.geoportal.lt

Wilkowski, W.; Karabin, M. 2006. Cadastre 2020 - a vision for a future cadastral system in Poland, in XXIII FIG Congress, 8-13 October, 2006, Munich, Germany.

Poyraz, N.; Ercan, O. 2002. The design, development and implementation of the Turkish land registry and cadastre information system, in XXII International FIG congress, 2002, 19-26 April, 2002, Washington D. C., USA.

Rummukainen, A. 2009. Contents of finnish Cadastral System, in FIG, Working Week Eilat, 3-8 May, 2009, Israel.

Yavuz, A. 2005. A comparative analysis of cadastral systems in EU countries according to basic selected criteria, in FIG Working Week Cairo, 16-21, April, 2005, Egypt.

Rimvydas GAUDE்ŠIUS. Master of Environmental engineering. Chief specialist of National land service under the Ministry of agriculture. Responsible for the state land administration. Main research area: spatial planning, real estate, geographic information technology. 